\title{
Characterization of the Microbial Community Involved in the Suppression of Pythium aphanidermatum in Cucumber Grown on Rockwool
}

\author{
Joeke Postma, Bart P. J. Geraats, Rob Pastoor, and Jan Dirk van Elsas
}

First, second, third, and fourth authors: Plant Research International BV, P.O. Box 16, 6700 AA Wageningen, The Netherlands; second author: Nunhems Zaden BV, P.O. Box 4005, 6080 AA Haelen, The Netherlands; and fourth author: Department of Microbial Ecology, P.O. Box 14, 9750 AA Haren, The Netherlands.

Accepted for publication 8 March 2005.

\begin{abstract}
Postma, J., Geraats, B. P. J., Pastoor, R., and van Elsas, J. D. 2005. Characterization of the microbial community involved in the suppression of Pythium aphanidermatum in cucumber grown on rockwool. Phytopathology 95:808-818.

The root pathogen Pythium aphanidermatum induced lower levels of disease in cucumber (Cucumis sativus) plants on unsterilized, re-used rockwool slabs than on heat-sterilized, re-used rockwool. Several recolonization treatments of the sterilized rockwool enhanced the suppressiveness of the rockwool. Microbial community structures in the different rockwool treatments were investigated by plate counts on selective media. Disease suppressiveness in the different rockwool treatments showed the highest correlation with the culturable number of filamentous actinomycetes in both experiments $(r=0.79$ and 0.94$)$, whereas the numbers of Trichoderma spp. correlated with suppression only in the first

with the plate counts were mainly Streptomyces spp., of which $10 \%$ were antagonistic toward P. aphanidermatum in dual culture. The composition of the bacterial and actinomycete populations was studied with polymerase chain reaction (PCR)-denaturing gradient gel electrophoresis (DGGE). Multivariate analyses of these patterns with canonical correspondence analysis showed significant correlations between the microbial composition and the disease suppressiveness. However, none of the bands in PCR-DGGE patterns occurred exclusively in the treatments that had enhanced disease suppressiveness. Bands extracted from the actinomycete-specific DGGE gels showed closest similarity with members of several actinomycete genera, i.e., Streptomyces, Mycobacterium, Microbacterium, Rhodococcus, Curtobacterium, and Tsukamurella. The possible mechanism of disease suppressiveness in used rockwool slabs, based on the results obtained with culture-dependent and culture-independent detection methods, is discussed.
\end{abstract} experiment (0.86). The numbers of total culturable bacteria, fluorescent pseudomonads, Bacillus spores, and fungi all showed lower correlations with disease suppressiveness. The filamentous actinomycetes enumerated
Additional keywords: community profiling, root and crown rot.
Pythium aphanidermatum (Edson) Fitzp. is a root pathogen that can cause serious losses in several greenhouse crops, especially when grown in soilless cultivation systems. It is the most widely reported Pythium species that can cause root rot in greenhouse cucumber $(10,19,22,23,30)$. Due to the production of zoospores, it can spread very quickly through substrates with high water retention capacity, such as rockwool. The pathogen is difficult to control. In the short term, there are no prospects for breeding resistant cultivars. Fungicides (i.e., propamocarb and metalaxyl) are only effective if used in preventive applications. Biological control is an environmentally friendly alternative. Microorganisms, such as Pseudomonas spp., Streptomyces spp., Trichoderma spp., Bacillus spp., and Pythium oligandrum, have the potential to control $P$. aphanidermatum $(3,18,23-25,32,36)$. However, results with these organisms have not led to an effective and reliable biocontrol agent becoming available on the market (23). The biocontrol effect is often disappointing or unreliable (25), especially when greenhouse temperatures are high.

A remarkable, but still poorly understood phenomenon, is the occurrence of disease suppressiveness in soilless systems (26). It was repeatedly demonstrated that a growing system is less sensitive to the development of Pythium root rot if the autochthonous microflora is still present compared with a sterilized system. The

Corresponding author: J. Postma; E-mail address: joeke.postma@wur.nl

DOI: 10.1094/PHYTO-95-0808

(c) 2005 The American Phytopathological Society mechanism of this disease suppression is of biological nature, since the loss of suppression after sterilization could be (partly) restored by the addition of the original microflora. Natural disease suppression in soils has been known for a long time and has been a source for several new antagonists, i.e., nonpathogenic $\mathrm{Fu}$ sarium oxysporum against Fusarium wilt (1), Verticillium biguttatum against Rhizoctonia solani (15), P. nunn against Pythium sp. (16), and 2,4-diacetylphloroglucinol producing Pseudomonas spp. against Gaeumannomyces graminis var. tritici (28). A better understanding of the mechanism of natural suppression of disease in rockwool and identification of the antagonistic organisms might result in more successful biocontrol strategies for artificial substrates.

The purpose of this work was to analyze the microorganisms in used rockwool slabs that are responsible for suppression of the disease caused by $P$. aphanidermatum in cucumber. Restoration of the disease suppression by the addition of a microbial suspension opened the possibility of manipulating the microflora present in this suspension, i.e., by filtration, heat treatment, or chemical inhibitors. Levels of disease in plants growing on such differently treated, used rockwool slabs were correlated with the microbial community structures in these slabs. The culturable fractions were analyzed by plate counts, enumerating different microbial groups on (semi-) selective media: i.e., bacteria in general, spore-forming bacteria, fluorescent pseudomonads, filamentous actinomycetes, total fungi, and Trichoderma spp. The community structure and diversity were analyzed by polymerase chain reaction-denaturing gradient gel electrophoresis (PCR-DGGE) of the total community 
DNA (20,21). Recently, several group-specific PCR-DGGE systems have been described, e.g., for actinomycetes (13), bacilli (11), and pseudomonads (12). This allows the study of specific, potentially antagonistic, groups in more detail. Since earlier results had shown differences in the bacterial composition of differently treated rockwool (26), bacterial PCR-DGGE was first applied in this study. As a result of the interesting findings on the basis of the cultural fraction of the actinomycetes, we also applied the actinomycete-specific method of Heuer et al. (13).

\section{MATERIALS AND METHODS}

Fungal pathogen. In all experiments, a mixture of $P$. aphanidermatum isolates 89 and 301 was used. These isolates were obtained from hydroponically grown cucumbers and were supplied by P. Paternotte (Applied Plant Research [PPO], Naaldwijk, NL). Isolates were cultured in 100-ml Erlenmeyer flasks containing $20 \mathrm{ml}$ of V8-liquid medium ( $200 \mathrm{ml}$ of vegetable juice V8 and $3 \mathrm{~g}$ of $\mathrm{CaCO}_{3}$ per liter of deionized water, autoclaved $20 \mathrm{~min}$ at $105^{\circ} \mathrm{C}$ ). Flasks were incubated for 7 days at $25^{\circ} \mathrm{C}$ in the dark without shaking. Then, mycelial mats were washed four times with $50 \mathrm{ml}$ of sterilized tap water, blended for $30 \mathrm{~s}$ at high speed in a blender (Waring, New Hartford, $\mathrm{CN}$ ), and filtered through a sieve (1 mm mesh). Oospores were counted with the aid of a hemacytometer. Stock cultures were stored in liquid nitrogen. Cultures for the experiments were kept on corn meal agar (Oxoid, London) with streptomycin at $100 \mathrm{mg} / \mathrm{liter}$ (Duchefa, Haarlem, $\mathrm{NL}$ ) and tetracycline at $10 \mathrm{mg} /$ liter (Duchefa) to avoid bacterial contamination.

Cultivation of plants on rockwool in an "ebb-and-flood" system. With a cork borer, 24-mm-diameter holes were made in rockwool cubes ( 4 by 4 by $4 \mathrm{~cm}$ ) (Grodan, Roermond, NL). These were saturated with a cucumber nutrient solution containing $972 \mathrm{mg}$ of $\mathrm{Ca}\left(\mathrm{NO}_{3}\right)_{2} \cdot 4 \mathrm{H}_{2} \mathrm{O}, 55 \mathrm{mg}$ of $\mathrm{NH}_{4} \mathrm{NO}_{3}, 557 \mathrm{mg}$ of $\mathrm{KNO}_{3}$, $20 \mathrm{mg}$ of Fe-DTPA (7\%), $170 \mathrm{mg}$ of $\mathrm{KH}_{2} \mathrm{PO}_{4}, 616 \mathrm{mg}$ of $\mathrm{MgSO}_{4} \cdot 7 \mathrm{H}_{2} \mathrm{O}, 140 \mathrm{mg}$ of $\mathrm{NaNO}_{3}, 1.7 \mathrm{mg}$ of $\mathrm{MnSO}_{4}, 1.45 \mathrm{mg}$ of $\mathrm{ZnSO}_{4} \cdot 7 \mathrm{H}_{2} \mathrm{O}, 3.35 \mathrm{mg}$ of $\mathrm{B}_{4} \mathrm{Na}_{2} \mathrm{O}_{7} \cdot 10 \mathrm{H}_{2} \mathrm{O}, 0.25 \mathrm{mg}$ of $\mathrm{CuSO}_{4} \cdot 5 \mathrm{H}_{2} \mathrm{O}$, and $0.12 \mathrm{mg}$ of $\mathrm{Na}_{2} \mathrm{MoO}_{4} \cdot 2 \mathrm{H}_{2} \mathrm{O}$ per liter of water; the $\mathrm{pH}$ was adjusted to 5.5 with $\mathrm{H}_{3} \mathrm{PO}_{4}$ and the electrical conductivity was $2.4 \mathrm{mS} / \mathrm{cm}$. A single cucumber seed (Cucumis sativus L., cv. Tyria, untreated) (ENZA Zaden, Enkhuizen, NL) was placed in the hole of each rockwool cube and covered with vermiculite. Cucumber seeds were allowed to germinate in closed containers exposed to a day/night rhythm of $16 \mathrm{~h} / 25^{\circ} \mathrm{C}$ (light intensity $>250 \mathrm{~W} / \mathrm{m}^{2}$ ) and $8 \mathrm{~h} / 20^{\circ} \mathrm{C}$ (dark) for 7 days. Then 12 young plants were divided over four rockwool slabs in each of the ebb-and-flood units. Details about the ebb-and-flood system have been described elsewhere (26).

Pythium suppressiveness assays. In two independent experiments, the disease development of cucumber plants on differently treated rockwool was assessed. Rockwool slabs $(6 \mathrm{~cm}$ high), previously used for the production of cucumber in two successive crops, were collected and cut into pieces $(20$ by $15 \mathrm{~cm})$. Part of the rockwool was sterilized by autoclaving $\left(20 \mathrm{~min}, 121^{\circ} \mathrm{C}\right)$, after which, part of this sterilized rockwool was allowed to become recolonized by different treatments.

In experiment 1 , the rockwool was treated as follows: 1 , no treatment; 2 , sterilization 2 days before planting; 3 , sterilization 9 days before planting; 4, sterilization 35 days before planting; 5 , sterilization 77 days before planting; 6 , sterilization 128 days before planting; 7, sterilization and placing in contact with nonsterilized used rockwool for 1.5 day; and 8, sterilization and inoculation with $8 \mathrm{~g}$ of suspended organic-waste compost per rockwool slab. The sterilized rockwool of treatments $3,4,5$, and 6 was stored at room temperature before it was placed in the ebband-flood system.

The treatments of experiment 2 were as follows: 1 , no treatment; 2 , sterilization 2 days before planting; 3 , sterilization as in treatment 2 and inoculation with $250 \mathrm{ml}$ of extracted liquid from nonsterilized rockwool per slab. Treatment 4 was similar to 3 , but the liquid was filtered through a $4-\mu \mathrm{m}$ polycarbonate filter (Millipore, Billerica, MA) and diluted 10 times prior to inoculation. Treatment 5 was similar to 3 , but the liquid was heated at $80^{\circ} \mathrm{C}$ for $20 \mathrm{~min}$ prior to inoculation. Treatment 6 was similar to 3, but the liquid was incubated with vancomycin at $100 \mathrm{mg} / \mathrm{liter}$ (Sigma, Zwijndrecht, NL) and cefotaxime at $100 \mathrm{mg} /$ liter (Sigma) for $6 \mathrm{~h}$ prior to inoculation. Treatment 7 was similar to 3 , but with the liquid was incubated with benomyl at $10 \mathrm{mg} /$ liter (Benlate, $50 \%$ a.i.; Du Pont de Nemours, Dordrecht, NL) for $6 \mathrm{~h}$ prior to inoculation. Treatment 8 consisted of sterilized rockwool enriched with a Trichoderma spore suspension $\left(1.5 \times 10^{8}\right.$ spores per slab) from 27 isolates which had been isolated previously from the nonsterilized rockwool. The antibiotics and benomyl had been tested for their effect on P. aphanidermatum; no serious inhibition of the mycelial growth was measured.

After these treatments, the rockwool slabs were saturated with nutrient solution and the next day, the surface of each slab was inoculated with $1.5 \times 10^{6}$ oospores of $P$. aphanidermatum (i.e., $6 \times$ $10^{6}$ oospores per ebb-and-flood unit). One day later, 7-day-old cucumber seedlings were placed on the slabs. Each treatment consisted of four independent units arranged in a randomized block design. The number of plants infected by $P$. aphanidermatum and showing symptoms typical of root and crown rot (brown stem base, wilted, and dead plants) was determined twice a week. Microbial populations were characterized by plate counts as well as by PCR-DGGE just after placement of the cucumber seedlings. In some treatments, the rockwool was additionally sampled at 9, 14, 21, and 28 days after sowing, or $0,1,2,4$, and 14 days after sterilization. Per treatment, two or three replicates were sampled.

Plate counts. Per treatment, two vertical cores $(2.5 \mathrm{~cm}$ diameter, $6 \mathrm{~cm}$ high) were cut out of the rockwool with a cork borer. These cores were pooled and cut in smaller parts of about $1 \mathrm{~cm}^{3}$. To determine the numbers of culturable microorganisms in the rockwool, at each sampling $30 \mathrm{~g}$ of rockwool was homogenized for $10 \mathrm{~min}$ at $440 \mathrm{rpm}$ in a $250-\mathrm{ml}$ Erlenmeyer flask containing $70 \mathrm{ml}$ of sterile $0.1 \%$ tetra sodium pyrophosphate $\left(\mathrm{Na}_{4} \mathrm{P}_{2} \mathrm{O}_{7} \cdot 10 \mathrm{H}_{2} \mathrm{O}\right)$ and $10 \mathrm{~g}$ of gravel. From this suspension, 5 to $10 \mathrm{ml}$ was filtered through two layers of cheesecloth. Appropriate dilutions were plated in triplicate on different media with a spiral plater (WASP, Don Whitley Scientific Limited, Shipley, UK). Total aerobic heterotrophic bacteria were enumerated on 1/10th-strength tryptic soy agar (TSA [Oxoid, Basingstoke, UK]; $4 \mathrm{~g}$ of TSA, $13.5 \mathrm{~g}$ of agar, and $100 \mathrm{mg}$ of cycloheximide per liter of deionized water). Endospore-forming bacteria were enumerated on TSA after the suspension had been heated at $80^{\circ} \mathrm{C}$ for $10 \mathrm{~min}$. Total fungal propagules were enumerated on $0.25 \times$ potato dextrose agar (PDA [Oxoid]; $10 \mathrm{~g}$ of PDA, $16 \mathrm{~g}$ of agar, $100 \mathrm{mg}$ of streptomycin, $10 \mathrm{mg}$ of tetracycline, and $2 \mathrm{ml}$ of Triton X-100 per liter of deionized water). Triton X-100 was added to PDA to limit mycelial growth. Trichoderma spp. could be distinguished on PDA by their color and growth characteristics. PDA and TSA plates were incubated for 7 days at $20^{\circ} \mathrm{C}$. Fluorescent pseudomonads were enumerated on King's B agar (KB; $20 \mathrm{~g}$ of proteose peptone No. 3 [Difco Laboratories, Detroit], $1.5 \mathrm{~g}$ of $\mathrm{K}_{2} \mathrm{HPO}_{4}, 1.5 \mathrm{~g}$ of $\mathrm{MgSO}_{4} \cdot 7 \mathrm{H}_{2} \mathrm{O}, 15 \mathrm{ml}$ of glycerol [99\%], $13.5 \mathrm{~g}$ of agar, and $100 \mathrm{mg}$ of cycloheximide per liter of deionized water) (under UV light) after 2 days incubation at $25^{\circ} \mathrm{C}$. Filamentous actinomycetes were enumerated after $100 \mu \mathrm{l}$ of the suspension had been plated manually on a sterile filter with $0.2-\mu \mathrm{m}$ pores (BA-S 83, Schleicher \& Schnell, Germany), which was placed on chitin-oatmeal agar (COA; $18 \mathrm{~g}$ of oatmeal agar (Difco), $0.7 \mathrm{~g}$ of $\mathrm{K}_{2} \mathrm{HPO}_{4}$, $0.3 \mathrm{~g}$ of $\mathrm{KH}_{2} \mathrm{PO}_{4}, 2 \mathrm{~g}$ of colloid chitin, $12 \mathrm{~g}$ of agar, and $100 \mathrm{mg}$ of cycloheximide per liter of deionized water). After 5 days of incubation at $25^{\circ} \mathrm{C}$, the filters were removed, and after another 5 days incubation, the colonies were counted. All data were 
calculated to correspond with colony forming units (CFU) per gram of moist rockwool.

Filamentous actinomycete isolates and in vitro inhibition of $\boldsymbol{P}$. aphanidermatum. Filamentous actinomycetes were isolated from used rockwool slabs and from closed growing systems with a cucumber crop using the selective COA medium with a bacterial filter. These isolates were tested for their antagonistic properties against the two Pythium isolates in dual culture on $0.25 \times$ PDA. The inhibition zone was measured after 3, 6, and 10 days of incubation at $25^{\circ} \mathrm{C}$. Inhibition was defined positive when no mycelium occurred within $\geq 4 \mathrm{~mm}$ from the actinomycetes isolate after 10 days. Eight isolates with different colony morphologies were selected for identification.

DNA extraction. The rockwool sampled for plate counts was also used to randomly select $2 \mathrm{~g}$ of rockwool with a pincet. DNA was extracted from these rockwool samples with a bead beater (Braun cell homogenizer; Braun, Melsungen, Germany) followed by phenol-chloroform extraction and purification with a Wizard DNA Clean-up Kit (Promega Benelux, Leiden, NL) as described by Postma et al. (26).

DNA from filamentous actinomycete isolates was extracted from colonies by cell lysis in $20 \mu \mathrm{l}$ of lysis buffer $(0.05 \mathrm{M} \mathrm{NaOH}$ and $0.2 \%$ sodium dodecyl sulfate in Milli-Q water), incubated for $15 \mathrm{~min}$ at $95^{\circ} \mathrm{C}$, and chilled on ice. After addition of $200 \mu \mathrm{l}$ of sterile Milli-Q water followed by centrifugation $(5 \mathrm{~min}$ at 12,000 rpm; Eppendorf centrifuge), $1 \mu \mathrm{l}$ of the supernatant (eventually 10 times diluted) was used as target for the PCR.

PCR amplification of bacterial DNA. A variable region, between positions 968 and 1401, of the bacterial 16S rDNA (Escherichia coli numbering system), was enzymatically multiplied in a touch-down PCR using two primers to conserved regions (14). The universal bacterial primers used were F968GC (including a GC clamp) and R1378 (13,26). PCR was performed in a Peltier Thermal Cycler-200 (Biozym, Landgraaf, NL) in 50- $\mu \mathrm{l}$ reaction volumes as described by Postma et al. (26). The thermal cycling was as follows: denaturation at $94^{\circ} \mathrm{C}$ for $4 \mathrm{~min}$, one cycle of $1 \mathrm{~min}$ at $94^{\circ} \mathrm{C}, 1 \mathrm{~min}$ at $60^{\circ} \mathrm{C}$ and $2 \mathrm{~min}$ at $72^{\circ} \mathrm{C}$ followed by 9 cycles in which the annealing temperature was lowered $0.5^{\circ} \mathrm{C}$ per cycle until $55^{\circ} \mathrm{C}$, at which temperature another 20 cycles were performed. Primer extension was done at $72^{\circ} \mathrm{C}$ for $10 \mathrm{~min}$, after which the amplification products were analyzed by electrophoresis in $1.2 \%$ agarose gels at $5 \mathrm{~V} / \mathrm{cm}$.

Actinomycete-specific PCR amplification. A nested PCR producing actinomycete-specific fragments was performed using primers F243 and R1378 in the first PCR (13). This PCR was performed in a Peltier Thermal Cycler-200 (Biozym) in a volume of $50 \mu \mathrm{l}$ containing 10 to $20 \mathrm{ng}$ of purified rockwool DNA, 1X Stoffelbuffer (Perkin Elmer), $200 \mu \mathrm{M}$ of each dNTP (Boehringer, Almere, NL), $3.75 \mathrm{mM} \mathrm{MgCl} 2,0.2 \mu \mathrm{M}$ primer $1,0.2 \mu \mathrm{M}$ primer $2,1 \%$ formamide (Merck, Amsterdam, NL), $0.25 \mu \mathrm{g}$ of T4 gene 32 protein (Boehringer), and 5 units of AmpliTaq DNA polymerase (Stoffelfragment; Perkin Elmer, Nieuwerkerk a/d IJssel, $\mathrm{NL}$ ). The thermal cycling was as follows: denaturation at $94^{\circ} \mathrm{C}$ for $4 \mathrm{~min}$, one cycle of $1 \mathrm{~min}$ at $94^{\circ} \mathrm{C}, 1 \mathrm{~min}$ at $63^{\circ} \mathrm{C}$, and $2 \mathrm{~min}$ at $72^{\circ} \mathrm{C}$ followed by nine cycles in which the annealing temperature was lowered $0.5^{\circ} \mathrm{C}$ per cycle until $58^{\circ} \mathrm{C}$, at which temperature another 22 cycles were performed. Primer extension was done at $72^{\circ} \mathrm{C}$ for $10 \mathrm{~min}$, after which the amplification products were analyzed by electrophoresis in $1.2 \%$ agarose gel. One microliter of product of the first PCR was used in a second PCR with the bacterial primers F968GC and R1378 (as described previously).

Denaturing gradient gel electrophoresis. Two acrylamide solutions with denaturant concentrations of 45 and $65 \%$ were obtained by mixing a $0 \%$ denaturant acrylamide solution and an $80 \%$ denaturant acrylamide solution in the proportions $11: 14$ and 4.7:20.3, respectively. The $0 \%$ denaturant solution consisted of $1 \times$ TAE (40 mM Tris base [Boehringer], $20 \mathrm{mM} \mathrm{NaAc}, 1 \mathrm{mM}$ EDTA (H 7.8), and 6\% acrylamide 4K Mix [AppliChem, Darm- stadt, Germany]). The $80 \%$ denaturant solution consisted of the same substances and $5.6 \mathrm{M}$ urea and $32 \%$ (vol/vol) deionized formamide (Merck). Gels with the 45 to $65 \%$ denaturant gradient were produced with a gradient mixer in a DGGE setup (Ingeny, Goes, NL). Polymerization of the gels was initiated by addition of $150 \mu \mathrm{l}$ of $10 \%$ (wt/vol) ammonium per sulphate (Bio-Rad, Veenendaal, NL) and $12 \mu \mathrm{l}$ of TEMED (Sigma) to $25 \mathrm{ml}$ of each acrylamide solution. A top layer of $5 \mathrm{ml}$ of $0 \%$ denaturant polyacrylamide gel was applied and the PCR products were added. Electrophoresis was performed in $0.5 \times \mathrm{TAE}$ at $100 \mathrm{~V}$ and $60^{\circ} \mathrm{C}$. After $16 \mathrm{~h}$, the DNA in the gel was stained by incubation with $0.5 \times$ TAE plus $0.025 \%$ SYBR Gold (Molecular Probes, Leiden, $\mathrm{NL}$ ) for 20 to $30 \mathrm{~min}$ and analyzed under UV-light.

Cloning and sequencing of actinomycete isolates. DNA of the actinomycete isolates was amplified in a Peltier Thermal Cycler-200 (Biozym) using primers F968 and R1401NC to amplify the V6 variable region between positions 968 and 1401 resulting in a 433-bp product for total bacteria (26). The PCR products were purified using a Qiaquick PCR purification kit (Westburg, Leusden, NL), and $1 \mu \mathrm{l}$ of PCR product was ligated in pGEM-T and transformed to E-coli JM109 (pGEM-T vector system and JM109; Promega Benelux) according to the pGEM-T manual. Per transformation, three white colony clones were randomly picked and grown overnight in a sterile $10 \mathrm{ml}$ polystyrene tube containing $3 \mathrm{ml}$ of $\mathrm{LB}+50 \mathrm{mg} / \mathrm{liter}$ ampicillin medium. Plasmid was isolated with a Wizard plus miniprep DNA purification system (Promega Benelux). Targeting the ligated fragment in the plasmids, a standard T7-Sp6 PCR was performed by standard conditions and the obtained fragments were sent for sequencing (Baseclear, Leiden, NL). These sequences were subjected to BLAST-N (available online by the National Center for Biotechnology Information [NCBI]).

Isolation and identification of bands from the DGGE gels. Separate bands were accurately cut from the DGGE gel with a scalpel. The band was placed in a $1.5-\mathrm{ml}$ Eppendorf tube with $20 \mu \mathrm{l}$ of sterile Milli-Q water. The tube was heated for $1 \mathrm{~h}$ at $60^{\circ} \mathrm{C}$ and then incubated overnight at $4^{\circ} \mathrm{C}$ to allow the DNA to elute out of the gel. Aliquots of the liquid $(10 \mu \mathrm{l})$ were then used as targets for PCR amplification of bacterial DNA as described previously, using primers F968 and R1378 without a GC clamp. Cloning, plasmid isolation, T7-SP6 PCR, and database searches using BLAST-N were performed as described for identification of filamentous actinomycetes.

Statistical analyses and analysis of DGGE patterns. Analyses of variance were carried out with the statistical program Genstat release 6.1 (Rothamsted Experimental Station, Harpenden, UK). After ANOVA, least significant differences (LSD) were calculated at a significance level of $P=0.05$. Numbers of microorganisms were analyzed after logarithmic $\left(\log _{10}(\mathrm{CFU}+1)\right)$ transformation. Correlation between mean values per treatment of disease suppression and numbers of microorganisms was evaluated first by preparing a correlation matrix (correlation coefficients, $r$ ) followed by linear regression analyses with Genstat release 6.1 (at $P=0.05$ ).

The DGGE patterns were analyzed using Molecular Analyst Fingerprinting software (version 1.61; Bio-Rad, Venendaal, NL) (29). Different gels were combined linearly (superimposed) using the gel markers. Data were quantified according to the heights of the peaks ( 3 pts position tolerance) and transported to Excel. The Shannon Weaver index $\left(H^{\prime}\right)$ was calculated as $H^{\prime}=$ $-\operatorname{sum}\left(n_{i} / N \times{ }^{e} \log n_{i} / N\right)$, with $n_{i}=$ peak height and $N=$ sum of all peak heights.

To perform the statistical analysis of the PCR-DGGE profiles and their correlation with disease suppressiveness, canonical correspondence analysis (CCA) was chosen $(31,34)$. Analyses were carried out on the relative peak heights of the DGGE bands using the statistical program CANOCO 4.5 (Biometris, Wageningen, $\mathrm{NL})$ using logarithmic transformation and intersample distance. 
Statistical significance of disease suppressiveness, as an environmental factor, was tested with the Monte Carlo permutation test. Numbers and Shannon Weaver diversity index of bacteria and actinomycetes were added to the ordination plots as supplementary (i.e., passive) variables. Both length and slope of the vectors are significant parameters. Vectors pointing in the same direction are positively correlated and the length of the vector represents its influence.

In the actinomycete patterns only the bands below the B marker were analyzed, because our results obtained with the actinomycete clones from the DGGE gels showed, in all cases, band positions below the B marker. Moreover, actinomycetes are known to have high GC levels and are therefore expected to migrate further downwards in the DGGE gel (high denaturant concentrations).

\section{RESULTS}

Suppression of Pythium disease. The percentage of cucumber plants with Pythium symptoms was significantly influenced by the different treatments of the used rockwool slabs (Fig. 1). The disease incidence increased drastically after sterilization of the used rockwool in both experiments. Recolonization of the sterilized rockwool by contact with nonsterilized rockwool (st+contact) (Fig. 1A), or by adding liquid extracted from nonsterilized rockwool (st+liquid) (Fig. 1B), resulted in lower disease percentages compared with the sterilized rockwool (st). In other words, the suppressiveness of the rockwool increased after these recolonization treatments. Exposure of the extracted liquid with antibiotics against gram-positive and gram-negative bacteria (vancomycin and cefotaxime) or a fungicide (benomyl) did not influence the suppressiveness. However, disease suppressiveness was not enhanced by the addition of a filtered or pasteurized extraction liquid, a mixture of Trichoderma isolates, a compost suspension, or incubation periods between 9 and 128 days at room temperature, even though recolonization showed a progressive increase of suppressive power with time.

Culturable microflora. Numbers of culturable bacteria in rockwool slabs were low (10 to $100 \mathrm{CFU} / \mathrm{g}$ of rockwool) immediately after sterilization by autoclaving $\left(20 \mathrm{~min}\right.$ at $\left.121^{\circ} \mathrm{C}\right)$. Two days after sterilization, during which time nutrient solution was added and young plants were placed on the treated rockwool slabs, the total numbers of culturable bacteria in the sterilized rockwool, or in any of the other treatments, were similar to, or higher than, those in the untreated rockwool (Table 1). In most sterilized and recolonized treatments, the numbers of culturable fluorescent pseudomonads increased (often 10-fold or more) above the level in the untreated rockwool 7 days after sowing (Table 1). However, a strong decrease in numbers of culturable spore-forming bacilli upon sterilization is shown. Only the treatments recolonized by contact (experiment 1) or by adding a pasteurized solution (experiment 2) had similar numbers of Bacillus spores compared with the nonsterilized treatments (Table 1).

The numbers of filamentous actinomycetes decreased significantly in the sterilized rockwool. Incubation of the rockwool slabs at room temperature for at least 128 days did not result in recovery of these numbers. Addition of a compost suspension to the sterilized rockwool, as well as recolonization due to contact with nonsterilized rockwool, or addition of liquid extracted from nonsterilized rockwool enhanced the numbers of actinomycetes. Filtration and pasteurization of the rockwool extracts, before adding these to the sterilized slabs, significantly reduced the numbers of actinomycetes, but the addition of antibiotics or benomyl had no great influence.

The numbers of culturable fungi were decreased by sterilization of the rockwool. After 9 and 35 days of incubation at room temperature, these numbers again were similar to those in untreated rockwool. Longer incubation at room temperature, or inoculation of sterilized rockwool with a compost suspension or contact with nonsterilized rockwool did not result in recovery of the fungal levels (experiment 1). Inoculation with the liquid extracted from nonsterilized rockwool, however, resulted in an increased level of fungi compared with the sterilized rockwool (experiment 2). The numbers of culturable fungi were reduced when the liquid was filtered or pasteurized prior to inoculation of sterilized slabs, but not by treatment with antibiotics or benomyl. Inoculation of sterilized rockwool with Trichoderma spp. resulted in an increased total number of fungi, and these numbers consisted mainly of Trichoderma spp. The effectiveness of benomyl was checked on nine fungi randomly isolated from the benomyl treatment; they were not found to be resistant to benomyl (10 mg/liter).
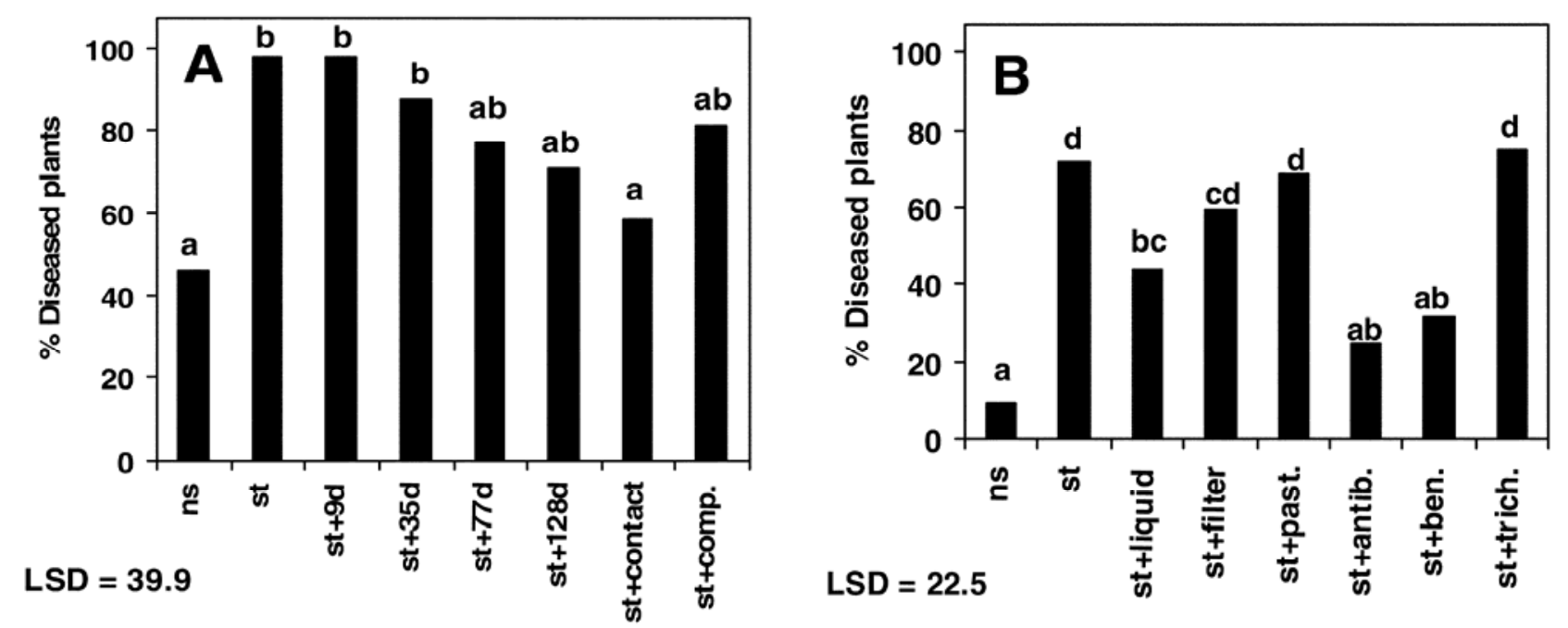

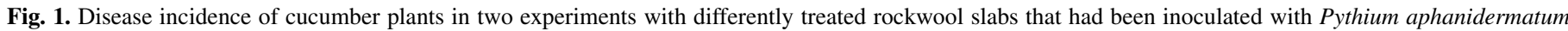

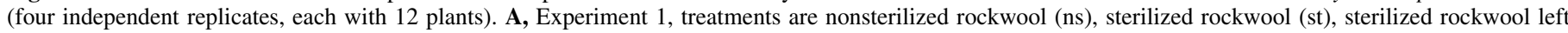

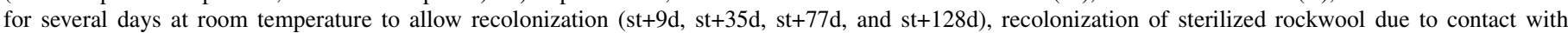

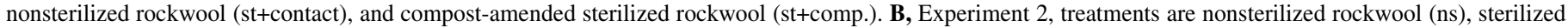

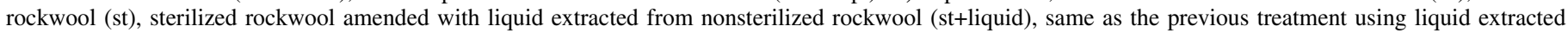

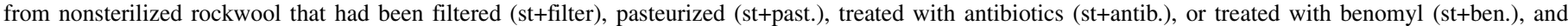

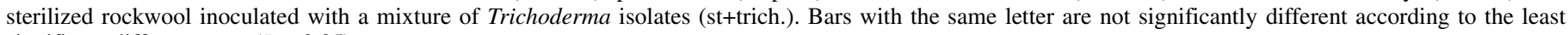
significant difference test $(P<0.05)$. 
The level of culturable Trichoderma spp. decreased upon sterilization, and did not revert to its original level during 128 days incubation at room temperature. Treatment of the sterilized rockwool with a compost suspension or contact with untreated rockwool enhanced the numbers of Trichoderma spp., although not to the level of untreated rockwool (experiment 1). After adding the liquid extracted from untreated rockwool to sterilized rockwool, the number of Trichoderma spp. was significantly higher than in untreated rockwool (experiment 2). Filtration and pasteurization of the liquid decreased the number of Trichoderma spp. Inoculation of sterilized rockwool with Trichoderma spp. resulted in a high level of Trichoderma species.

Correlation between disease incidence and microbial populations. In both experiments, the highest negative correlations were found between disease incidence and numbers of filamentous actinomycetes $(-0.79$ and -0.94 in experiments 1 and 2 , respectively) (Table 1). Using linear regression, the following lines were fitted (Fig. 2): experiment $1, Y=99.5-7.2 \times A$, accounting for $55 \%$ of the variance; and experiment $2, Y=76.0-9.7 \times A$, accounting for $86 \%$ of the variance, with $Y=\%$ diseased plants at the end of the experiment and $A=\log$ CFU filamentous actinomycetes 7 days after sowing.

Numbers of Trichoderma spp. also showed a high correlation with disease incidence $(-0.86)$, but only in experiment 1 . Numbers of Bacillus spores also were negatively correlated with disease incidence in both experiments $(-0.53$ and -0.56$)$, but Bacillus spp. and all other microbial groups showed lower correlation values than the actinomycetes or were inconsistent between experiments. For fluorescent pseudomonads, a positive correlation with disease incidence was found in experiment 2 (i.e., increased numbers of pseudomonads correlated with more disease, possibly an indication of a microbiologically unstable system).

Filamentous actinomycete isolates and in vitro inhibition of P. aphanidermatum. Eight filamentous actinomycete isolates were identified by the sequencing of $16 \mathrm{~S}$ ribosomal RNA gene fragments. Highest similarity was found with different Streptomyces spp. (6×), Cellulomonas cellulans (1×), and Micromonospora sp. $(1 \times)$ (similarity levels $>97 \%)$. The PCR-DGGE bands of the Streptomyces and Cellulomonas isolates were all located between marker $\mathrm{C}$ and halfway between marker $\mathrm{D}$ and $\mathrm{E}$, whereas the Micromonospora isolate had the lowest band, at the height of marker E (data not shown).

From the used rockwool slabs, 73 Streptomyces-type isolates (recognizable by their powdery colony morphology) were obtained. Eight of these isolates strongly ( $\geq 4 \mathrm{~mm}$ inhibition) inhibited Pythium spp. Also, four Micromonospora-type (orange to brown, tiny pin-prick like colonies) and one Cellulomonas isolate (yellow colony) were obtained. None of these isolates inhibited Pythium spp.

Bacterial community profiles. Band numbers in the bacterial community profiles decreased significantly in all treatments that had been sterilized in experiment 2 (Table 2). Average band numbers decreased from 29.3 bands in the nonsterilized treatment to

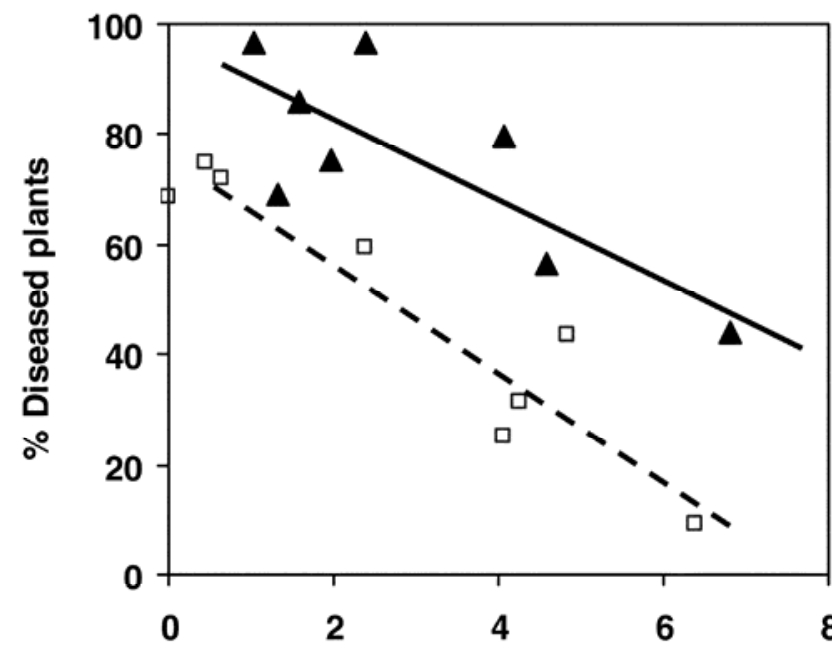

\section{Log CFU actinomycetes/ g rockwool}

Fig. 2. Fitted and observed relation between disease incidence at the end of both experiments $(Y)$ and logarithmic numbers of filamentous actinomycetes 7 days after sowing $(A)$. Experiment 1, closed triangles with fitted line: $Y=$ $99.5-7.2 \times A$. Experiment 2, open squares with fitted dotted line: $Y=76.0-$ $9.7 \times A$.

TABLE 1. Microbial populations (log CFU/g of moist rockwool) in the different treatments of used rockwool slabs, 7 days after sowing the cucumber cropa

\begin{tabular}{|c|c|c|c|c|c|c|}
\hline Treatment & Bacteria & $\begin{array}{c}\text { Fluorescent } \\
\text { pseudomonads }\end{array}$ & Bacillus spores & $\begin{array}{l}\text { Filamentous } \\
\text { actinomycetes }\end{array}$ & Fungi & Trichoderma spp. \\
\hline \multicolumn{7}{|l|}{ Experiment 1} \\
\hline Nonsterilized & 7.50 & 6.23 & 6.31 & 6.93 & 5.11 & 4.42 \\
\hline Sterilized (st) & 7.79 & $\mathrm{ND}^{\mathrm{b}}$ & 4.32 & 2.53 & 2.61 & 0.63 \\
\hline$s t+9 d$ & 7.88 & ND & 5.12 & 1.20 & 5.28 & 0 \\
\hline $\mathrm{st}+35 \mathrm{~d}$ & 7.45 & 6.41 & 4.20 & 1.73 & 5.45 & 0 \\
\hline $\mathrm{st}+77 \mathrm{~d}$ & 7.25 & 7.19 & 1.27 & 2.12 & 2.99 & 0 \\
\hline $\mathrm{st}+128 \mathrm{~d}$ & 7.55 & 7.42 & 2.09 & 1.47 & 2.73 & 0 \\
\hline st+contact & 7.47 & 7.34 & 6.27 & 4.72 & 3.55 & 2.40 \\
\hline st+compost & 7.53 & 6.77 & 5.13 & 4.22 & 2.94 & 1.50 \\
\hline $\operatorname{LSD}^{\mathrm{c}}(P=0.05)$ & 0.32 & 0.56 & 2.20 & 1.43 & 1.11 & 1.45 \\
\hline Correlation $^{\mathrm{d}}$ with disease at day 29 & -0.22 & 0.09 & -0.53 & -0.79 & -0.18 & -0.86 \\
\hline \multicolumn{7}{|l|}{ Experiment 2} \\
\hline Nonsterilized & 7.83 & 5.81 & 5.60 & 6.40 & 4.35 & 0.70 \\
\hline Sterilized (st) & 8.20 & 7.16 & 3.14 & 0.63 & 0 & 0 \\
\hline st+liquid & 8.38 & 7.55 & 4.73 & 4.84 & 3.16 & 2.76 \\
\hline st+filter & 8.35 & 7.56 & 4.06 & 2.38 & 1.61 & 0 \\
\hline st+past. & 8.31 & 7.44 & 5.82 & 0 & 1.61 & 0 \\
\hline st+antib. & 7.91 & 6.73 & 4.39 & 4.05 & 4.05 & 2.63 \\
\hline st+ben. & 7.89 & 7.20 & 4.60 & 4.26 & 2.83 & 1.91 \\
\hline st+trich. & 7.93 & 7.40 & 1.96 & 0.46 & 4.82 & 4.79 \\
\hline $\operatorname{LSD}^{c}(P=0.05)$ & 0.49 & 0.53 & 0.64 & 0.60 & 1.09 & 1.11 \\
\hline Correlation ${ }^{\mathrm{d}}$ with disease at day 35 & 0.56 & 0.76 & -0.56 & -0.94 & -0.50 & -0.01 \\
\hline
\end{tabular}

a Two days following sterilization of the rockwool slabs.

${ }^{\mathrm{b}} \mathrm{ND}=$ not determined.

c LSD = least significant difference.

${ }^{\mathrm{d}}$ Correlation coefficient $(r)$ between $\log$ CFU and percent diseased plants. 
14.5 bands in the sterilization treatment at day 7, whereas the sterilized and recolonized treatments varied between 13 and 19.3 bands. Although the differences in band numbers among treatments were not significant in experiment 1 , there was a trend indicating lower numbers after sterilization. At later sampling dates (days 9, 14, 21, and 28), the numbers of bands in the sterilization treatment increased, whereas numbers in the nonsterilized rockwool decreased (Fig. 3), and the PCR-DGGE profiles showed increased similarity between these treatments (ns, st, and st+liquid). There was a negative correlation between the initial numbers of bands as well as the Shannon Weaver index of the bacterial community profiles with the disease incidence in the rockwool treatments (between -0.60 and -0.84) (Table 2).

All rockwool treatments had a clear influence on the banding patterns of the bacterial PCR-DGGE profiles. Since the profiles themselves were too complex to compare, ordination plots obtained with the multivariate technique CCA are presented (Fig. 4). In both experiments, the disease suppressiveness significantly correlated with the bacterial composition of the different treatments $(P=0.02$ and 0.002). Treatments with highest disease suppressiveness were most positive on the $x$ axis (i.e., ns), whereas the least suppressive treatments were most negative on the $x$ axis (i.e., st, st+9, st+past, and st+trich). The Shannon Weaver diversity index of bacterial and actinomycete community profiles, as well as the logarithmic number of culturable actinomycetes, were positively associated with the disease suppressiveness, since these vectors pointed in the same direction (Fig. 4). Despite the significant correlation between the DGGE patterns and the disease suppressiveness, no bands occurring exclusively in all (or most) of the disease suppressive treatments could be detected by visual evaluation.

Actinomycete community profiles. Although the DGGE patterns were different between the treatments (Figs. 5 and 6), the numbers of bands as well as the Shannon Weaver indices in actinomycete DGGE profiles were not significantly influenced by the treatments (Table 2). Multivariate analysis of the PCR-DGGE patterns with CCA showed a significant correlation between the disease suppressiveness and the actinomycete composition of the different treatments in experiment $1(P=0.03)$, but not in experiment $2(P=0.25)$. In fact, there was considerable variation between replicates of the same treatments (Figs. 5 and 6).

Similar to the bacterial patterns, CCA of the actinomycete patterns showed a strong positive correlation between disease suppressiveness and the logarithmic number of actinomycetes, and a weaker, but always positive, contribution of the Shannon Weaver diversity index of bacterial and actinomycete communities to the disease suppressiveness (Fig. 4). No bands occurring exclusively

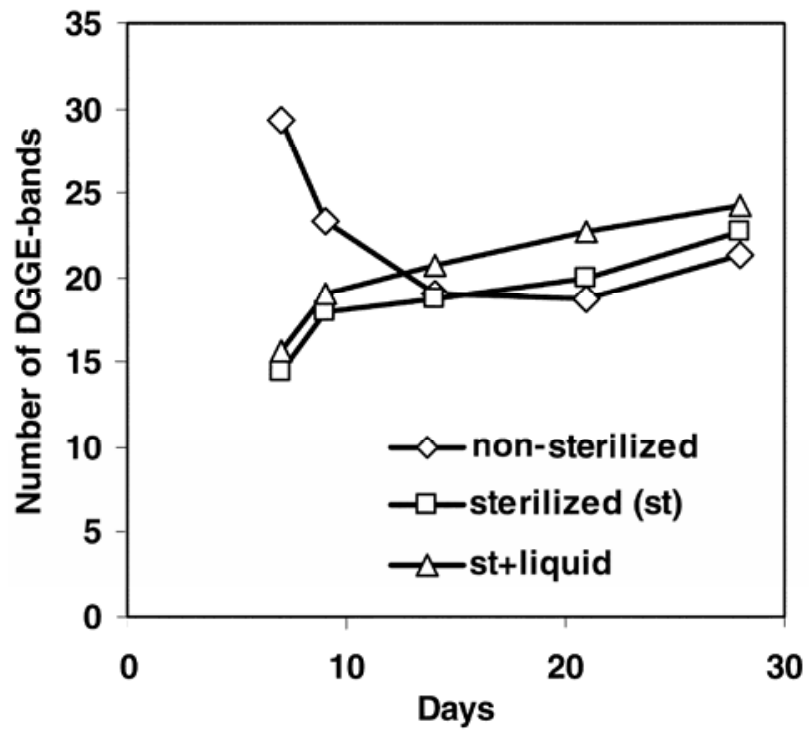

Fig. 3. Dynamics of the number of bands in the bacterial polymerase chain reaction-denaturing gradient gel electrophoresis (PCR-DGGE) patterns of three main rockwool treatments in experiment 2 up to day 28. Treatments are nonsterilized rockwool slabs (ns), sterilized rockwool slabs (st), and sterilized rockwool slabs that were recolonized with liquid extracted from nonsterilized rockwool (st+liquid). Interaction between time and treatment is significant, and the least significant difference is 4.6.

TABLE 2. Number of bands and Shannon Weaver diversity index $\left(H^{\prime}\right)$ of the bacterial and actinomycete polymerase chain reaction-denaturing gradient gel electrophoresis patterns of the different rockwool treatments in experiment 1 and 2 at day 7

\begin{tabular}{|c|c|c|c|c|}
\hline \multirow[b]{2}{*}{ Treatment } & \multicolumn{2}{|c|}{ Bacteria } & \multicolumn{2}{|c|}{ Actinomycetes } \\
\hline & No. of bands ${ }^{\mathrm{a}}$ & $H^{\prime}$ a & No. of bands ${ }^{a}$ & $H^{\prime a}$ \\
\hline \multicolumn{5}{|l|}{ Experiment 1} \\
\hline Nonsterilized & 25.5 & 2.85 & 22.0 & 2.86 \\
\hline$s t+9 d$ & 17.0 & 2.50 & 14.0 & 2.28 \\
\hline$s t+35 d$ & 16.0 & 2.60 & 18.5 & 2.65 \\
\hline$s t+77 d$ & 23.5 & 3.00 & 16.5 & 2.45 \\
\hline st + compost & 19.5 & 2.70 & 18.0 & 2.57 \\
\hline $\operatorname{LSD}^{\mathrm{b}}(P=0.05)$ & $\mathrm{ns}$ & $\mathrm{ns}$ & ns & ns \\
\hline Correlation $^{\mathrm{c}}$ with disease at day 29 & -0.62 & -0.60 & -0.84 & -0.70 \\
\hline \multicolumn{5}{|l|}{ Experiment 2} \\
\hline Nonsterilized & 29.3 & 3.10 & 19.3 & 2.64 \\
\hline Sterilized (st) & 14.5 & 2.25 & 19.0 & 2.69 \\
\hline st+liquid & 15.7 & 2.40 & 19.7 & 2.69 \\
\hline $\operatorname{LSD}^{\mathrm{b}}(P=0.05)$ & 4.5 & 0.21 & ns & ns \\
\hline Correlation $^{\mathrm{c}}$ with disease at day 35 & -0.76 & -0.84 & -0.60 & -0.23 \\
\hline
\end{tabular}

a Mean of two and three replicates in experiments 1 and 2, respectively.

${ }^{\mathrm{b}} \mathrm{LSD}=$ least significant difference, $\mathrm{ns}=$ not significantly different.

${ }^{\mathrm{c}}$ Correlation coefficient $(r)$ between percent diseased plants and number of bands or $H^{\prime}$.

${ }^{\mathrm{d}} \mathrm{ND}=$ not determined 
in all (or most) of the disease suppressive treatments could be distinguished on day 7 (Figs. 5 and 6) or at later sampling days (data not shown).

Persistence of actinomycete DNA after sterilization. PCRDGGE patterns of the actinomycete population from rockwool samples taken immediately after sterilization were similar to the nonsterilized samples (data not shown). At 1 and 2 days after sterilization, most of the original bands had disappeared and few new bands became visible. At later sampling days (days 4 and $14)$, increasing numbers of new bands occurred in the actino-
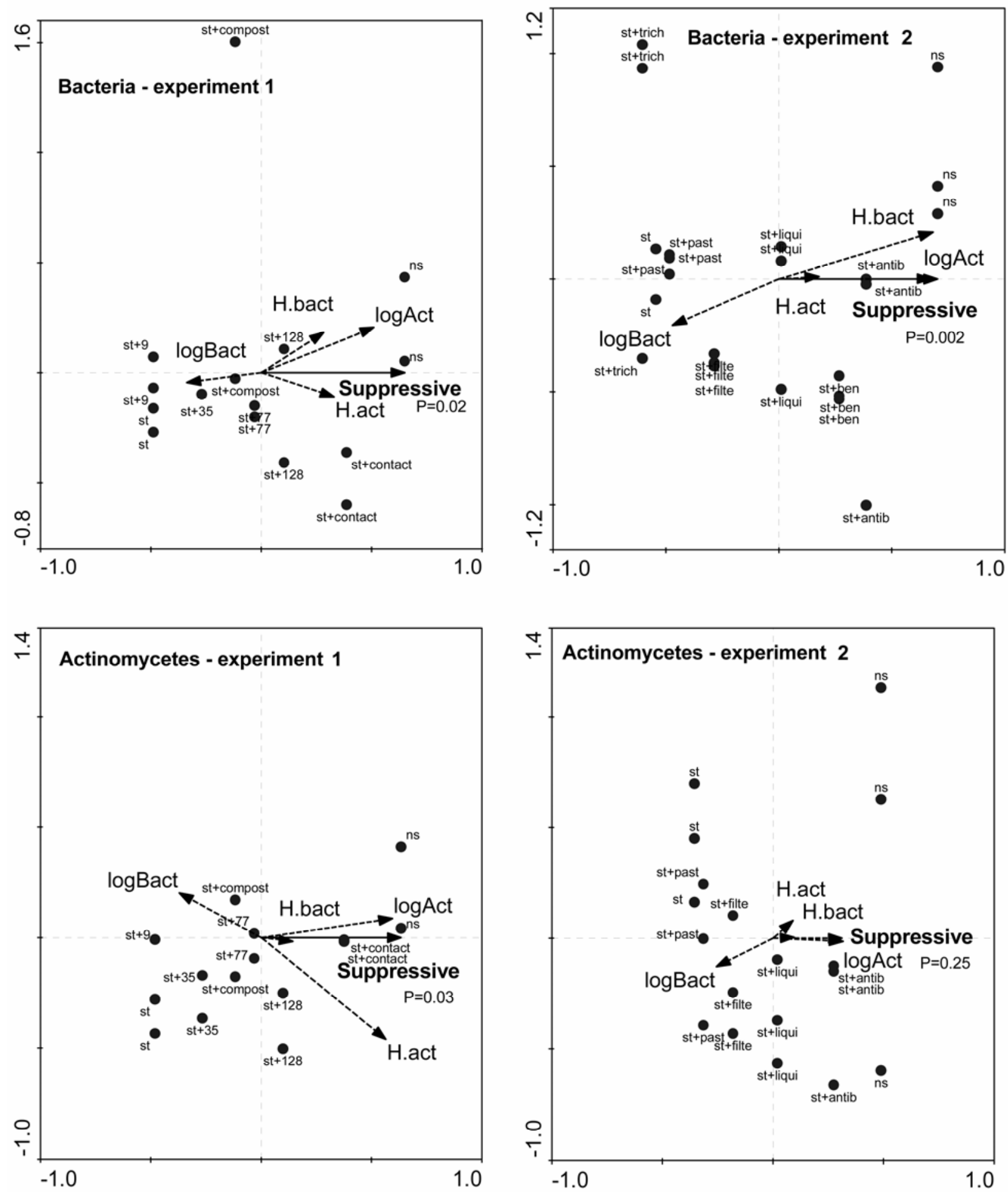

Fig. 4. Ordination plots of bacterial and actinomycete communities in differently treated rockwool slabs. Plots were generated by canonical correspondence analysis of polymerase chain reaction-denaturing gradient gel electrophoresis (PCR-DGGE) profiles. Significance of the variable disease suppressiveness is expressed by its $P$ value. Arrows with dashed lines represent the supplementary (passive) variables: numbers of bacteria (logBact), numbers of filamentous actinomycetes (logAct), and Shannon Weaver diversity index of bacteria (H.bact) and of actinomycetes (H.act). The treatments are nonsterilized rockwool (ns), sterilized rockwool (st), sterilized rockwool left for several days at room temperature to allow recolonization (st $+9 \mathrm{~d}$, st $+35 \mathrm{~d}$, st $+77 \mathrm{~d}$, and st $+128 \mathrm{~d}$ ), recolonization of sterilized rockwool due to contact with nonsterilized rockwool (st+contact), compost-amended sterilized rockwool (st+compost), sterilized rockwool amended with liquid extracted from nonsterilized rockwool (st+liqui), same as the previous treatment using liquid extracted from nonsterilized rockwool but treated in various ways, filtered (st+filte), pasteurized (st+past), treated with antibiotics (st+antib), or treated with benomyl (st+ben), and sterilized rockwool inoculated with a mixture of Trichoderma isolates (st+trich). 
mycete-specific PCR-DGGE. These results showed a clear shift in the actinomycete DNA profile starting 1 day after sterilization.

Identity of bands. Several bands, mainly from the disease suppressive treatments (nonsterilized and recolonized), were extracted and sequenced. The sequences of one or more clones originating from 17 bands were successfully matched with sequences in the database (Table 3). If the similarity of a clone exceeded $96 \%$, the best match was presented in the table. For several of the bands, $100 \%$ similarity was found with the database. Ninety percent of all bands matched with actinomycetes or unknown uncultured bacteria. The genera detected were Streptomyces (4×), Mycobacterium (6x), Microbacterium (6x), Rhodococcus (5x), Curtobacterium $(1 \times)$, Tsukamurella $(1 \times)$, and some unknown or uncultured bacteria $(4 \times)$. Sphingobacterium $(2 \times)$ and Bdellovibrio $(1 \times)$, both gram-negative bacteria, were the only nonactinomycete genera found. The position of these nonactinomycete clones in the PCR-DGGE gel was above the B marker, whereas all actinomycete clones showed lower positions in the gel.

In general, it appeared to be difficult to relate the bands in the PCR-DGGE patterns with actinomycete species, because there was often a discrepancy between the location of extracted bands in the PCR-DGGE gels and that of several of the clones. The band dominantly present in almost all treatments in which the rockwool had been sterilized (between D and E marker) showed high similarity to Rhodococcus sp. (Figs. 5 and 6).

\section{DISCUSSION}

Previous research (26) has shown that nonsterilized, used rockwool slabs were suppressive toward $P$. aphanidermatum in a cucumber crop. This disease suppression had a biological origin, since the loss of suppression in sterilized rockwool could be restored by recolonization of the sterilized rockwool. It was shown that the microbial population had been changed due to the different treatments, but there was no indication about the mechanism of the suppressiveness. In the present study, several different recolonization treatments resulting in different levels of disease

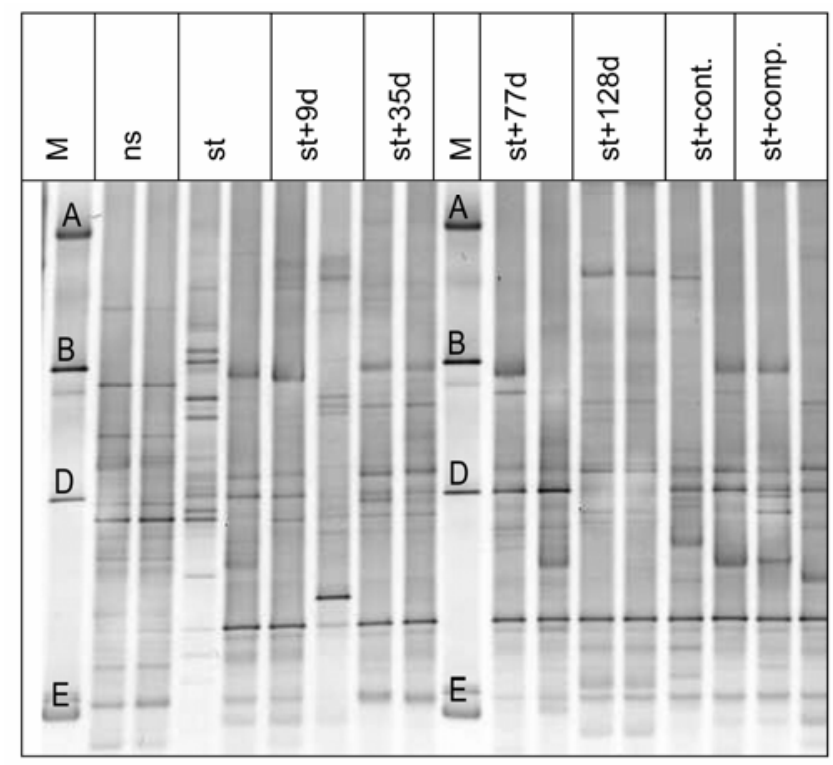

Fig. 5. Polymerase chain reaction-denaturing gradient gel electrophoresis of actinomycetes 7 days after sowing in experiment 1 in different rockwool treatments. Treatments are nonsterilized rockwool (ns), sterilized rockwool (st), sterilized rockwool left for several days at room temperature to allow recolonization $(s t+9 d, s t+35 d, s t+77 d$, and $s t+128 d)$, recolonization of sterilized rockwool due to contact with nonsterilized rockwool (st+cont.), and compostamended sterilized rockwool (st+comp.). The marker contained the following bacterial isolates: Enterobacter cloaceae BE1 (A), Listeria innocua ALM105 (B), Arthrobacter sp. (D), and Burkholderia cepacia P2 (E). suppressiveness were tested, and compared with the accompanying microbial population, to provide a better understanding of the causal agents of the disease suppression. Culture-dependent (plate counts) and culture-independent (PCR-DGGE) techniques were applied. Population dynamics of total bacteria, pseudomonads, total fungi, and Trichoderma spp. were studied as in the previous experiments (26). In addition, filamentous actinomycetes and spore-forming bacilli, known for their antagonistic properties, were studied. Because of the highly interesting results in the present study on the basis of the culturable fraction of the actinomycetes, the actinomycete-specific PCR-DGGE was applied in

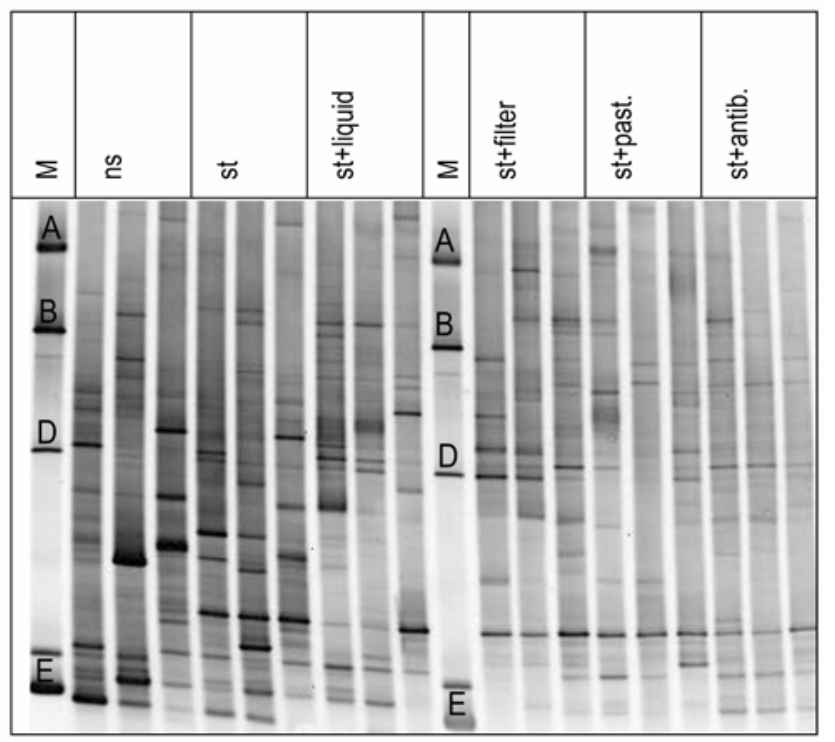

Fig. 6. Polymerase chain reaction-denaturing gradient gel electrophoresis of actinomycetes 7 days after sowing in experiment 2 in different rockwool treatments. Treatments are nonsterilized rockwool (ns), sterilized rockwool (st), sterilized rockwool amended with liquid extracted from nonsterilized rockwool (st+liquid), same as the previous treatment using liquid extracted from nonsterilized rockwool but treated in various ways, filtered (st+filter), or pasteurized (st+past.), or treated with antibiotics (st+antib.). The marker contained the following bacterial isolates: Enterobacter cloaceae BE1 (A), Listeria innocua ALM105 (B), Arthrobacter sp. (D), and Burkholderia cepacia $\mathrm{P} 2(\mathrm{E})$.

TABLE 3. Best match of sequenced bands from actinomycete polymerase chain reaction-denaturing gradient gel electrophoresis gels

\begin{tabular}{|c|c|}
\hline Sequences in NCBI database & $\%$ Similarity \\
\hline Bdellovibrio sp. AF148940 (B. starrii AF084852) & 98 \\
\hline Curtobacterium fangii AY273209 & 97 \\
\hline Microbacterium sp. AF306541 & 99 \\
\hline Microbacterium sp. AY278889 (5×) & 97-99 \\
\hline Mycobacterium conspicuum X88922 & 98 \\
\hline Mycobacterium frederiksbergense AF544628 & 100 \\
\hline Mycobacterium gadium X55594 (M. moriokae AJ428044) & 99 \\
\hline Mycobacterium heidelbergense AJ422048 & 97 \\
\hline Mycobacterium manitobense AY082001 & 98 \\
\hline Mycobacterium sp. AF494537 (Actinobacterium AY162040) & 99 \\
\hline Rhodococcus erythropolis AY147846 & 100 \\
\hline Rhodococcus sp. AJ302331 & 97 \\
\hline Rhodococcus sp. AY249053 (3×) & 100 \\
\hline \multicolumn{2}{|l|}{ Sphingobacterium sp. AB076874 } \\
\hline (S. multivorum AB100739) $(2 \times)$ & 100 \\
\hline Streptomyces capoamus AB045877 & 99 \\
\hline $\begin{array}{l}\text { Streptomyces sp. AF112167 (S. scabiei AY094370; } \\
\text { S. scabies AF112167) }(2 \times)\end{array}$ & 99 \\
\hline Streptomyces sp. AY295794 & 100 \\
\hline Tsukamurella spumae AY238513 & 100 \\
\hline Uncultured bacterium AF432618 & 96 \\
\hline Unidentified bacterium AB021362 & 98 \\
\hline Unidentified maize root bacterium Zmrls35 AF531474 (2×) & 100 \\
\hline
\end{tabular}


addition to the total bacterial PCR-DGGE. Such a detailed study on the actinomycete population in rockwool samples has never been done before.

Disease suppression was restored by contact with untreated rockwool, as well as by adding a suspension extracted from the untreated rockwool. The rather short (1 day) and local contact, as well as the limited amount of added suspension, indicates that multiplication and transport of the suppressive factor probably occurred within the sterilized rockwool. The influence of different treatments on the suppressiveness provided circumstantial evidence about the causal agents of suppression. Since pasteurization of the suspension entirely removed suppressiveness, Bacillus sp. is not likely to be involved. The causal agents were also not present among the isolated Trichoderma spp. Filtration partly removed the suppressiveness, whereas the antibiotics and fungicide had no effect at all on the suppressiveness. These treatments are not distinctive: filtration removes a much larger part from the population than only the fraction $>4 \mu \mathrm{m}$, and the temporal exposure to the antibiotics or fungicides probably does not kill all targeted organisms. Several reasons can be given: antibiotics are often bacteriostatic instead of bactericidal, mainly growing microorganisms are killed by the antibiotics or fungicide, and spores probably survive the treatments.

More information about the causal agent of suppression was obtained by comparing the abundance of different microbial groups in the microflora and the disease suppressiveness of each treatment. All sterilized rockwool treatments were quickly recolonized by culturable bacteria and fluorescent pseudomonads. However, this did not result in an increased disease suppression for all treatments. Culturable numbers of spore-forming bacilli related to disease suppression in some treatments. However, with the addition of the pasteurized suspension, the numbers of Bacillus spores increased drastically, whereas the disease suppression decreased. Numbers of filamentous actinomycetes were drastically reduced by sterilization, whereas their numbers recovered in several recolonization treatments. The relation between disease suppression and the numbers of filamentous actinomycetes was obvious in all treatments, except for the treatment in which a compost extract was added. This is likely due to different types of actinomycetes being present in the compost that are not adapted to the rockwool systems. As a consequence, a high correlation coefficient was found between numbers of culturable filamentous actinomycetes and disease suppression in both experiments $(-0.79$ and -0.94$)$. This correlation could be significantly expressed with a straight line. A correlation between disease suppressiveness and actinomycetes has been reported for natural substrates such as soil, peat, and compost $(7,35,38)$, but never for artificial substrates such as rockwool. Numbers of culturable fungi and Trichoderma spp. were also drastically reduced by sterilization. Several recolonization treatments increased these numbers, but the correlation with disease suppression was only high for Trichoderma spp. in experiment $1(-0.86)$. Since there was no good correlation in the second experiment, Trichoderma spp. as well as fungi, in general, are expected to be of less importance for the suppressiveness than the filamentous actinomycetes.

Another aspect of the microbial populations studied was their composition and diversity in relation to disease suppression. PCR-DGGE profiles of the bacterial and actinomycete populations differed among treatments. To compare the complex banding patterns of the different treatments, multivariate analysis is needed. Previously, canonical variate analysis has been used to analyze DGGE patterns (17). However, to apply this technique, the number of samples should be greater than the number of species (34), which is not the case in the present study. CCA does not have this disadvantage (34) and is a powerful technique to show the correlation between environmental factors and the banding patterns (31). CCA showed a significant correlation between disease suppressiveness and the composition of the bacterial com- munity in both experiments. For the actinomycete population, this was only the case in the first experiment. The strong positive relation between disease suppressiveness and the number of culturable actinomycetes was illustrated in the ordination plots, and again stresses the potential role of actinomycetes in suppression of Pythium spp. Diversity (Shannon Weaver index) of the bacterial as well as the actinomycete PCR-DGGE patterns had a lesser influence on the disease suppressiveness, but showed a positive association in all cases. In spite of the differences between the microbial communities in the different rockwool treatments, none of the bands in the PCR-DGGE patterns occurred exclusively in all (or most) of the disease suppressive treatments, as was found in earlier experiments (26). Three bacterial PCRDGGE bands, which occurred only in the two suppressive treatments and not in the sterilized treatment (26), are now identified as Serratia marcescens (100\% similarity), Pseudomonas sp. (98\% similarity), and Pseudomonas putida (100\% similarity) (unpublished data). These species are known for their antagonistic and root colonizing ability $(24,27)$.

Actinomycete-specific PCR-DGGE has been used in a few ecological studies $(4,5,13)$. In these studies, isolates as well as mixed populations have been analyzed, but no information on band identities has been reported yet. Extracting, cloning, and sequencing bands from the actinomycete-specific PCR-DGGE gel revealed positive as well as negative aspects of the applied technique. On the positive side, only $10 \%$ of the clones showed high similarity with nonactinomycete strains. On the negative side, the location of the clones often did not match with the location of the band from which the DNA was extracted, and clones from the same position sometimes matched with different genera. Several possible explanations can be given for this phenomenon, one being the occurrence of considerable amounts of heteroduplexes in the gel (33), and the other one being the simple occurrence of background DNA in each position of the gel. The high GC content of actinomycetes (62 to $74 \%$ for the detected genera) (37) might stimulate this heteroduplex formation in the actinomycetespecific PCR-DGGE profiles.

The bands from the actinomycete-specific PCR-DGGE patterns which were sequenced showed high similarity (96 to $100 \%$ ) with sequences in the database of the following genera: Mycobacterium, Microbacterium, Rhodococcus, Streptomyces, Curtobacterium, and Tsukamurella. Of these genera, Streptomyces spp. are known for their high antagonistic potential $(6,8)$, and several biocontrol agents of soilborne pathogens are based on Streptomyces isolates (i.e., Mycostop, Verdera, Finland; Rhizovit, Prophyta, Germany; and Actinovate, Natural Industries Inc., USA) $(2,23)$. In the present study, several antagonistic Streptomyces strains were isolated from used rockwool slabs.

Results of the present study, comparing culturable numbers and genetic profiles of dominant species with disease suppression, allows the following speculations on the mechanism of disease suppressiveness in used rockwool slabs. It should be taken into consideration that the presented results are merely correlative, not providing direct causations.

First of all, the strong correlation that was detected between the disease suppressiveness and the population size of the culturable filamentous actinomycetes suggests that actinomycetes play an important role in suppression of Pythium spp. Filamentous actinomycetes are effective colonizers of organic materials such as dead roots. Dead roots are abundantly present in used rockwool. Without competition, i.e., in the sterilized treatments, Pythium spp. will colonize these dead roots and produce tremendous amounts of zoospores. Filamentous actinomycetes, especially if they are able to inhibit Pythium spp., might prevent the dead roots from being colonized by Pythium, and as a consequence decrease numbers of zoospores. Streptomyces spp. were the dominant species enumerated by the plate counts, and about $10 \%$ of them were able to inhibit mycelial growth of $P$. aphanidermatum. The actinomy- 
cete-specific PCR-DGGE, which detects filamentous as well as unicellular actinomycete species, did not give more information about the composition of the suppressive component in the rockwool. Probably a more specific PCR-DGGE system, only detecting filamentous actinomycetes or Streptomyces spp., is needed for further research on the mechanism of disease suppression in rockwool

Secondly, the composition and diversity of bacterial and/or actinomycete populations might play an additional role in the disease suppressiveness, since the Shannon Weaver diversity index of bacteria and actinomycetes was always positively associated to the disease suppressiveness. Efficient root colonizing bacteria will be needed to prevent fresh roots from the attack by zoospores. Surfactant as well as antibiotic-producing bacteria, or competition for root exudates $(9,24)$ can be effective mechanisms to control Pythium zoospores from infecting fresh roots. Pseudomonas spp. (24) and Lysobacter enzymogenes (9) occur on cucumber roots and are able to inhibit infection by $P$. aphanidermatum. $S$. marcescens, which occurred specifically in the PCR-DGGE patterns of disease suppressive rockwool (26), is able to induce systemic resistance against fungal diseases in cucumber (27). Our results, so far, showed that Bacillus spp. are not likely to be part of the suppressive microflora, since pasteurization destroyed the disease suppressiveness. The cucumber root-colonizing bacterial species should already be present in the rockwool from the start of the experiment to be capable to colonize the cucumber roots at an early stage. However, such species can only be detected with PCR-DGGE if they are dominant within the detected population due to the limited number of detectable bands.

A complementary strategy between unicellular and filamentous microorganism, as suggested in the previous paragraph, could lead to a more reliable way of controlling $P$. aphanidermatum. Until now, all biocontrol efforts using one antagonist have failed for effectiveness and reproducibility in controlling $P$. aphanidermatum in cucumber grown in artificial substrate $(23,25)$. A better understanding of the disease suppressiveness in rockwool will hopefully lead to more effective biological control agents, probably containing combinations of organisms, and will enable growers to create more balanced growing systems towards severe disease attacks.

\section{ACKNOWLEDGMENTS}

This research was supported by the Dutch Ministry of Agriculture, Nature and Food Quality. We thank L. Lankwarden, D. Killaars, and M. Willemsen-de Klein for their practical assistance and ENZA Zaden BV for providing cucumber seeds.

\section{LITERATURE CITED}

1. Alabouvette, C., Rouxel, F., and Louvet, J. 1979. Characteristics of Fusarium wilt-suppressive soils and prospects for their utilization in biological control. Pages 165-182 in: Soil-Borne Plant Pathogens. B. Schippers and W. Gams, eds. Academic Press, New York.

2. Berg, G., Marten, P., Minkwitz, A., and Bruckner, S. 2001. Efficient biocontrol of fungal plant diseases by Rhizovit (R) on the basis of Streptomyces sp. DSMZ 12424. IOBC/WPRS Bull. 24:121-124.

3. Bolton, A. T. 1980. Control of Pythium aphanidermatum in poinsettia in a soilless culture by Trichoderma viride and a Streptomyces sp. Can. J. Plant Pathol. 2:93-95.

4. Boon, N., De Windt, W., Verstraete, W., and Top, E. M. 2002. Evaluation of nested PCR-DGGE (denaturing gradient gel electrophoresis) with group-specific 16S rRNA primers for the analysis of bacterial communities from different wastewater treatment plants. FEMS Microbiol. Ecol. 39:101-112.

5. Clegg, C. D., Lovell, R. D. L., and Hobbs, P. J. 2003. The impact of grassland management regime on the community structure of selected bacterial groups in soils. FEMS Microbiol. Ecol. 43:263-270.

6. Coombs, J., and Franco, C. M. M. 2003. Isolation and identification of actinobacteria from surface-sterilized wheat roots. Appl. Environ. Microbiol. 69:5603-5608.
7. Craft, C. M., and Nelson, E. B. 1996. Microbial properties of composts that suppress damping-off and root rot of creeping bentgrass caused by Pythium graminicola. Appl. Environ. Microbiol. 62:1550-1557.

8. Crawford, D. L., Lynch, J. M., Whipps, J. M., and Ousley, M. A. 1994. Isolation and characterization of actinomycete antagonists of a fungal root pathogen. Appl. Environ. Microbiol. 59:3899-3905.

9. Folman, L. B., Postma, J., and Van Veen, J. A. 2003. Characterization of Lysobacter enzymogenes (Christensen and Cook 1978) strain 3.1T8, a powerful antagonist of fungal diseases of cucumber. Microbiol. Res. 158:107-115.

10. Fravin, R. J., Rahe, J. E., and Mauza, B. 1988. Pythium spp. associated with crown rot of cucumbers in British Columbia greenhouses. Plant Dis. 72:683-687.

11. Garbeva, P., van Veen, J. A., and van Elsas, J. D. 2003. Predominant Bacillus spp. in agricultural soil under different management regimes detected via PCR-DGGE. Microbiol. Ecol. 45:302-316.

12. Garbeva, P., van Veen, J. A., and van Elsas, J. D. 2004. Assessment of the diversity and antagonism against Rhizoctonia solani AG3 of Pseudomonas species in soil from different agricultural regimes. FEMS Microbiol. Ecol. 47:51-64.

13. Heuer, H., Krsek, M., Baker, P., Smalla, K., and Wellington, E. M. H. 1997. Analysis of actinomycete communities by specific amplification of genes encoding 16S rRNA and gel-electrophoretic separation in denaturing gradients. Appl. Environ. Microbiol. 63:3233-3241.

14. Heuer, H., and Smalla, K. 1997. Application of denaturing gradient gel electrophoresis and temperature gradient gel electrophoresis for studying soil microbial communities. Pages 353-373 in: Modern Soil Microbiology. J. D. Van Elsas, J. T. Trevors, and E. M. H. Wellington, eds. Marcel Dekker, New York.

15. Jager, G., ten Hope, A., and Velvis, H. 1979. Hyperparasites of Rhizoctonia solani in Dutch potato fields. Neth. J. Plant Pathol. 14:86-91.

16. Lifshitz, R., Stanghellini, M. E., and Baker, R. 1984. A new species of Pythium isolated from soil in Colorado. Mycotaxon 20:373-379.

17. McCaig, A. E., Glover, L. A., and Prosser, J. I. 2001. Numerical analysis of grassland bacterial community structure under different land management regimes by using $16 \mathrm{~S}$ ribosomal DNA sequence data and denaturing gradient gel electrophoresis banding patterns. Appl. Environ. Microbiol. 67:4554-4559.

18. McCullagh, M., Utkhede, R., Menzies, J. G., Punja, Z. K., and Paulitz, T. C. 1996. Evaluation of plant growth-promoting rhizobacteria for biological control of Pythium root rot of cucumbers grown in rockwool and effects on yield. Eur. J. Plant Pathol. 102:747-755.

19. Moulin, F., Lemanceau, P., and Alabouvette, C. 1994. Pathogenicity of Pythium species on cucumber in peat-sand, rockwool and hydroponics. Eur. J. Plant Pathol. 100:3-17.

20. Muyzer, G., De Waal, E. C., and Uitterlinden, A. G. 1993. Profiling of complex microbial populations by denaturing gradient gel electrophoresis analysis of polymerase chain reaction-amplified genes coding for $16 \mathrm{~S}$ rRNA. Appl. Environ. Microbiol. 59:695-700.

21. Muyzer, G., Hottenträger, S., Teske, A., and Wawer, C. 1996. Denaturing gradient gel electrophoresis of PCR-amplified 16S rDNA-A new molecular approach to analyse the genetic diversity of mixed microbial communities. Mol. Microbiol. Ecol. Man. 3.4.4:1-23.

22. Paternotte, S. J. 1992. Influence of growing conditions on disease development of Pythium in glasshouse cucumbers on rockwool. Meded. Fac. Landbouwwet. Rijksuniver. Gent 57:373-379.

23. Paulitz, T. C., and Bélanger, R. R. 2001. Biological control in greenhouse systems. Annu. Rev. Phytopathol. 39:103-133.

24. Paulitz, T. C., Zhou, T., and Rankin, L. 1992. Selection of rhizosphere bacteria for biological control of Pythium aphanidermatum on hydroponically grown cucumber. Biological Control 2:226-237.

25. Postma, J., Willemsen-de Klein, M. J. E. I. M., Rattink, H., and van Os, E. A. 2001. Disease suppressive soilless culture systems; Characterisation of its microflora. Acta Hortic. 554:323-332.

26. Postma, J., Willemsen-de Klein, M. J. E. I. M., and van Elsas, J. D. 2000. Effect of the indigenous microflora on the development of root and crown rot caused by Pythium aphanidermatum in cucumber grown on rockwool. Phytopathology 90:125-133.

27. Press, C. M., Loper, J. E., and Kloepper, J. W. 2001. Role of iron in rhizosphere-mediated induced systemic resistance of cucumber. Phytopathology 91:593-598.

28. Raaijmakers, J. M., and Weller, D. M. 1998. Natural plant protection by 2,4-diacetylphloroglucinol-producing Pseudomonas sp. in take-all decline soils. Mol. Plant-Microbe Interact. 11:144-152.

29. Rademaker, J. L. W., Louws, F. J., Rossbach, U., Vinuesa, P., and de Bruijn, F. J. 1999. Computer-assisted pattern analysis of molecular fingerprints and database construction. Pages 1-33 in: Molecular Microbial Ecology Manual 7.1.3. A. D. L. Akkermans, J. D. van Elsas, and F. J. de Bruijn. eds. Kluwer Academic Publishers, Dordrecht, the Netherlands. 
30. Rankin, L., and Paulitz, T. C. 1994. Evaluation of rhizosphere bacteria for biological control of Pythium root rot of greenhouse cucumbers in hydroponic culture. Plant Dis. 78:447-451.

31. Salles, J. F., van Veen, J. A., and van Elsas, J. D. 2004. Multivariate analysis of Burkholderia species in soil: Effect of crop and land use history. Appl. Environ. Microbiol. 70:4012-4020.

32. Sivan, A., Elad, Y., and Chet, I. 1984. Biological control effects of a new isolate of Trichoderma harzianum on Pythium aphanidermatum. Phytopathology 74:498-501.

33. Speksnijder, A. G. C. L., Kowalchuk, G. A., de Jong, S., Kline, E., Stephen, J. R., and Laanbroek, H. J. 2001. Microvariation artifacts introduced by PCR and cloning of closely related 16S rDNA gene sequences. Appl. Environ. Microbiol. 67:467-472.

34. Ter Braak, C. J. F. 1995. Ordination. Pages 91-173 in: Data Analysis in Community and Landscape Ecology. 2nd ed. R. H. G. Jongman,
C. J. F. ter Braak, and O. F. R. van Tongeren, eds. Cambridge University Press, Cambridge, UK.

35. Tuitert, G., Szczech, M., and Bollen, G. J. 1998. Suppression of Rhizoctonia solani in potting mixtures amended with compost made from organic household waste. Phytopathology 88:764-773.

36. Utkhede, R. S., Koch, C. A., and Menzies, J. G. 1999. Rhizobacterial growth and yield promotion of cucumber plants inoculated with Pythium aphanidermatum. Can. J. Plant Pathol. 21:265-271.

37. Williams, S. T., Sharpe, M. E., and Holt, J. G. (eds.) 1989. Bergey's Manual of Systemic Bacteriology. Williams \& Wilkins, Baltimore, MD.

38. Workneh, F., and van Bruggen, A. H. C. 1994. Microbial density, composition, and diversity in organically and conventionally managed rhizosphere soil in relation to suppression of corky root of tomatoes. Appl. Soil Ecol. 1:219-230. 